\title{
An Investigation of Heavy Metal Exposure and Risks to Wildlife in the Kafue Flats of Zambia
}

\author{
Michelo SYAKALIMA $^{1)}$, Kennedy CHOONGO ${ }^{1)}$, Yoshikazu NAKAZATO ${ }^{1)}$, Misao ONUMA ${ }^{2}$, , Chihiro SUGIMOTO ${ }^{1)}$, \\ Toshio TSUBOTA ${ }^{3)}$, Hideto FUKUSHI ${ }^{3)}$, Mitsutoshi YOSHIDA ${ }^{4)}$, Tadashi ITAGAKI ${ }^{5)}$ and Jun YASUDA ${ }^{6) *}$ \\ ${ }^{1)}$ Laboratory of Disease Control, School of Veterinary Medicine, University of Zambia, P.O Box 32379, Lusaka, Zambia, ${ }^{2)}$ Graduate \\ School of Veterinary Medicine, Hokkaido University, Sapporo 060-0818, ${ }^{3}$ Division of Veterinary Medicine, Faculty of Agriculture, Gifu \\ University, Gifu 501-1193, ${ }^{4}$ Laboratory of Animal Reproduction, Faculty of Agriculture, Kagoshima University, Kagoshima 890-0065, \\ ${ }^{5)}$ Department of Veterinary Medicine, and ${ }^{6)}$ Veterinary Teaching Hospital, Faculty of Agriculture, Iwate University, Morioka 020-8550, \\ Japan.
}

(Received 2 June 2000/Accepted 2 November 2000)

ABSTRACT. Exposure and ecological risks to heavy metals (copper, zinc, manganese, iron) at Lochnivar and Blue Lagoon National Parks in wildlife dependent on the Kafue river contaminated with mining waste was evaluated. Samples included water, fish, grasses and Kafue Lechwe (Kobus leche kafuensis) liver. At both parks copper ranged from $0.03-0.04 \mathrm{mg} / \mathrm{l} ; 3.0-6.0 \mathrm{mg} / \mathrm{kg} ; 11.0-44.0 \mathrm{mg} / \mathrm{kg}$; trace -199.0 $\mathrm{mg} / \mathrm{kg}$; while zinc was $0.01 \mathrm{mg} / \mathrm{l} ; 32.0-82.0 \mathrm{mg} / \mathrm{kg} ; 15.0-21.0 \mathrm{mg} / \mathrm{kg}$; and $52.0-138.0 \mathrm{mg} / \mathrm{kg}$; in water, fish, grasses and lechwe, respectively. Manganese ranges were $0.15-0.16 \mathrm{mg} / \mathrm{l} ; 7.0-18.0 \mathrm{mg} / \mathrm{kg} ; 51.0-145.0 \mathrm{mg} / \mathrm{kg}$; and $40.0-53.0 \mathrm{mg} / \mathrm{kg}$ while iron ranges were $0.13-$ $0.14 \mathrm{mg} / \mathrm{l} ; 26.0-134.0 \mathrm{mg} / \mathrm{kg} ; 1766.0-1797.0 \mathrm{mg} / \mathrm{kg}$; and131.0-856.0 mg/kg; in water, fish, grasses and lechwe, respectively. Levels in all samples except water were high indicating potential for adverse effects.

KEY WORDS: heavy metal, Kafue river, wildlife.

J. Vet. Med. Sci. 63(3): 315-318, 2001

Food chain analysis of wildlife exposures to metals has received increasing attention over the past years particularly with the recent emphasis on assessing ecological risks at hazardous waste sites $[2,5,14,15]$. At mining waste contaminated areas, elevations of metals have been observed in a variety of wildlife species including plants and whether these increases pose a risk of adverse impacts to the exposed organisms along the food chain is still an ongoing concern $[2,4,11]$.

The Kafue river in Zambia has been found to be highly polluted with heavy metals from the mining waste upstream around the Copperbelt mining area declining as the river flows downstream [10]. The heavy metals implicated include: copper $(\mathrm{Cu})$, cobalt $(\mathrm{Co})$, zinc $(\mathrm{Zn})$ and other elements that are used by the copper processing industry in the Copperbelt mining area of Zambia. Downstream, the river is a resource to the Kafue Flats where the largest national park in the nation, the Kafue National Park and other smaller parks, Lochnivar and Blue Lagoon National Parks are found. The flats are of particular ecological and economic importance especially with regard to water resources, livestock, wildlife, fisheries, agriculture and tourism (Fig. 1).

It is therefore this study's concern that pollution by these metals may impact greatly on these ecological and economic factors and result in adverse effects to both primary consumers and higher trophic organisms through the food chain. In this study, therefore, copper, iron, manganese and zinc levels in water, grass and lechwe liver were investi-

* Correspondence to: Yasuda, J., Veterinary Teaching Hospital, Faculty of Agriculture, Iwate University, Morioka 020-8550, Japan. gated. This was done in order to analyze the magnitude of exposure and the likely risks to the dependents of the Kafue river water. The Kafue Lechwe (Kobus Leche Kafuensis) is the focus of study because it is the most abundant wildlife species in the area and is of greatest social and economic importance (Fig. 2). Sharing of grazing and drinking spots between the Kafue lechwe and cattle in the area has been documented by Suzuki et al. [12]. It is therefore felt that because of this mingling the data derived here may have a bearing on cattle and eventually humans in the area thus further justifying heavy metal pollution monitoring.

Samples collected in the study included water, fish, plants and Kafue lechwe liver tissues. Water was collected at the common drinking spots. Most animals drink clear top flowing water a few meters from the edge of the river. Water was thus collected in these spots in more the same manner as the animal would when drinking. This was done to ensure that the sample collected was as much as possible representative of that drunk by the animals.

Three common fish species were sampled. These include: Tilapia rendalli, Clarias gariepinus and Brycinus lateralis. Tilapia rendalli and Brycinus lateralis are both herbivorous whereas Clarias gariepinus is mostly carnivorous. Fish were collected from fishing camps that were very close to the area of study.

Grass was collected in the frequently grazed areas. The areas chosen were those in game management areas where obvious mingling between cattle and lechwe was observed. The most abundant grasses of the areas were sampled and pooled. They were then preserved in a polythene bag and frozen until processing.

In case of animal tissue, twelve Kafue lechwe liver sam- 


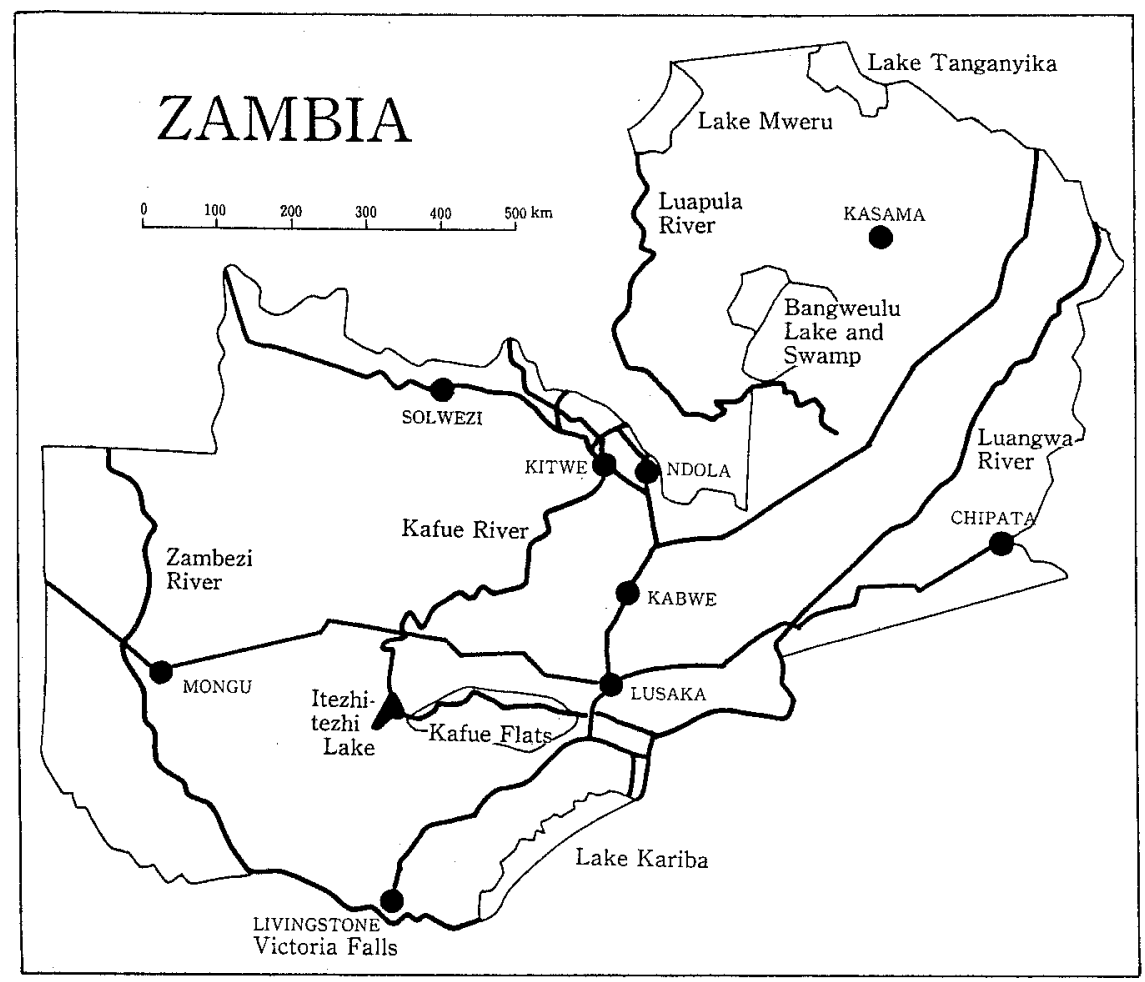

Fig. 1. A simplied geographical map of Zambia showing the course of the Kafue river from the Copperbelt mining area of Kitwe through the Kafue flats (Kafue flood plains which was the area of study) down into Lake Kariba.

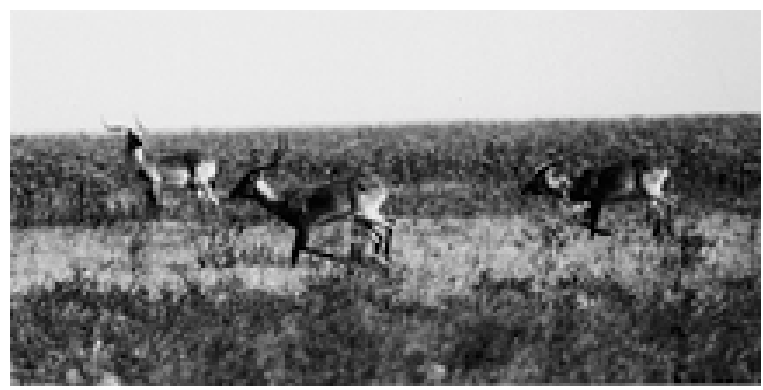

Fig. 2. Kafue Lechwe (Kobus leche kafuensis).

ples were used in this experiment. Of these samples, 6 were from Lochnivar and the other 6 were from Blue Lagoon National Parks i.e. south and north banks, respectively, in the Kafue Flats. The hunting licences were obtained from the department of National Parks and Wildlife Services. The samples were put in polythene bottles and frozen at $22^{\circ} \mathrm{C}$ until time of processing.

Samples were processed using wet digestion. The liver/ plant samples were left overnight in an oven at $120^{\circ} \mathrm{C}$. The resultant dry matter was minced to powder and oven dried to remove all moisture at $70^{\circ} \mathrm{C}$ for $4 \mathrm{hr}$ and cooled in a silica dessicator. One gram of this powder was mixed with $10 \mathrm{mls}$ of concentrated nitric acid and digested on a hot plate at approximately $250^{\circ} \mathrm{C}$ until all organic matter had been dissolved. It was then cooled and $10 \mathrm{mls}$ of distilled water followed by $10 \mathrm{mls}$ of perchloric acid added. The resultant fluid was again put on a hot plate and digested until solution was clear or when white fumes emerged. It was further cooled and $24 \mathrm{mls}$ of water added then brought to boil. It was again cooled and the solution made up to $100 \mathrm{mls}$ with distilled water then used for the atomic absorption spectophotometry (AAS) measurement. The solution was read in $\mathrm{mg} / \mathrm{l}$ of each element but calculated to $\mathrm{mg} / \mathrm{kg}$ using the formula:

$\mathrm{mg} / \mathrm{kg}=\mathrm{mg} / \mathrm{l}$ (conc.) $\mathrm{x}$ Vol. of extractant/ Weight of sample used 
Table 1. Concentrations of heavy metals in water, fish, grasses and Kafue lechwe liver samples taken from Lochnivar and Blue Lagoon National Parks

\begin{tabular}{|c|c|c|c|c|c|}
\hline \multirow[t]{2}{*}{ Sample } & \multirow{2}{*}{$\begin{array}{l}\text { Sample } \\
\text { size }\end{array}$} & \multicolumn{4}{|c|}{ Heavy metals } \\
\hline & & $\mathrm{Cu}$ & $\mathrm{Fe}$ & $\mathrm{Mn}$ & $\mathrm{Zn}$ \\
\hline Liver-L (mg/kg) & 6 & trace- 144.0 & $399.0-856.0$ & $40.0-53.0$ & $70.0-131.0$ \\
\hline mean \pm SEM & & $42.8 \pm 22.1$ & $556.7 \pm 90.2$ & $44.5 \pm 1.9$ & $90.5 \pm 9.0$ \\
\hline Liver-BL (mg/kg) & 6 & $24.0-199.0$ & $131.0-341.0$ & $41.0-46.0$ & $52.0-138.0$ \\
\hline mean \pm SEM & & $75.7 \pm 26.4$ & $206.0 \pm 33.5$ & $42.8 \pm 0.7$ & $76.0 \pm 12.8$ \\
\hline Grass-BL (mg/kg) & $1^{*}$ & 44 & 1797 & 51 & 15 \\
\hline Grass-L (mg/kg) & $1^{*}$ & 11 & 1766 & 145 & 21 \\
\hline Fish-CG (mg/kg) & $1 *$ & 3.0 & 26 & 7.0 & 32 \\
\hline Fish-TR (mg/kg) & $1^{*}$ & 6.0 & 59 & 13 & 51 \\
\hline Fish-BL (mg/kg) & $1^{*}$ & 4.0 & 134.0 & 18.0 & 82.0 \\
\hline Water-L (mg/L) & $1 *$ & 0.04 & 0.14 & 0.16 & 0.01 \\
\hline Water-B (mg/L) & $1^{*}$ & 0.03 & 0.13 & 0.15 & 0.01 \\
\hline
\end{tabular}

Liver-L: lechwe liver samples from Lochnivar, Liver-BL: lechwe liver samples from Blue Lagoon, GrassL: grass from Lochnivar, Grass-BL: grass from Blue Lagoon, Fish-CG: Clarias gariepinus, Fish-TR: Tilapia rendalli, Fish-BL: Brycinus lateralis, Water-L: water from Lochinivar, Water-BL: water from Blue Lagoon, $1^{*}$ : pooled samples.

Volume of extractant being $100 \mathrm{mls}$ while weight of sample is $1 \mathrm{gm}$.

No digestion was done on water. Water was directly taken for atomic absorption spectrophotometry and measured in $\mathrm{mg} / \mathrm{l}$.

The results of the AAS measurements of the heavy metal levels in water, fish, commonly grazed grasses and animal tissue (liver) are presented below in Table 1.

Although previous studies $[8,10]$ have shown that water from the Kafue river, especially around the Copperbelt mining area is heavily polluted with heavy metals; $\mathrm{Cu}, \mathrm{Co}, \mathrm{Zn}$, $\mathrm{Fe}$ and $\mathrm{Mn}$, samples collected from drinking spots at Lochnivar and Blue Lagoon National Parks had less dramatic levels of heavy metals, as shown in Table 1. The concentration of these metals were even less than those recommended by WHO on drinking water for humans which are $1.2 \mathrm{mg} / \mathrm{l}$, $3.0 \mathrm{mg} / \mathrm{l}, 0.5 \mathrm{mg} / \mathrm{l}$ and $0.3 \mathrm{mg} / \mathrm{l}$ for $\mathrm{Cu}, \mathrm{Zn}, \mathrm{Mn}$ and $\mathrm{Fe}$, respectively. A number of factors could have been responsible for the observed low levels. First and foremost, heavy metals are known to coat to plants, particles, algaes and insects in the river [3] and thus are unavailable in the surface smooth flowing water which was sampled. Secondly, the sediment has been identified in many studies to be where most heavy metals are trapped [8, 10] and as such only when there is activity that would disturb the separation between sediment and surface water flow would surface water heavy metal levels increase. Lastly, water was sampled a few meters from the edge so that it could represent that normally drank by lechwe and livestock. However, lechwes are semi-aquatic and may drink their water deep in the middle of the river where the water is actively flowing and is more polluted than near the edge. This therefore implies that the concentration of heavy metals ingested by the animals in drinking water may not necessarily be as low as that reflected in the water sampled. Previous studies have actually shown that concentration of metals in the Kafue river downstream from mining areas is still higher than those reported for major rivers draining the African continent $[6,7]$ and as such these animals ingest more pollutants on the average.

Uptake of metals in fish is mainly through their food. Herbivorous fish are probably of importance in this respect due to feeding on plants. At the primary producer level, plants take up metals both from water and sediment and thus tend to have higher concentrations than even the sediment. These metals in plants are then convented into the bioavailable form that herbirous fish and animals encounter. However, fish also take up metals directly from water through their gills and skin and are a very important factor in monitoring metals along the food chain. Fish, apart from being very important in the monitoring of pollution can also suffer from adverse effects after exposure to heavy metals. In a study [8] conducted near our area of sampling, fish exposed to the sediment were noted to have pathological changes ranging from reproductive abnormalities, hepatocellular necrosis, degenerative changes in gills to mortality. Our study did not endeavor to characterise any pathology but because of the proximity it is likely that such pathologies exist.

The liver is an important organ involved in metabolic processes and in detoxification of xenobiotics. Unfortunately, some of these xenobiotics have a tendency to accumulate in the liver reaching toxic levels that cause pathological alterations [1]. In cattle the upper limit for $\mathrm{Cu}$ accumulation in liver tissue for chronic toxicity to be observed was found to be $560 \mathrm{mg} / \mathrm{kg}$ (1). Levels above the upper limit mentioned above have been implicated in a number of pathological conditions such as a hemolytic crisis in animals and man. Subacute $\mathrm{Cu}$ toxicity has also been observed in sheep at ranges between 107-691 mg/kg liver 
dry weight [1]. The levels of up to $199 \mathrm{mg} / \mathrm{kg} \mathrm{Cu}$ dry weight in liver tissue observed in lechwe liver during this study are within this range and if lechwes are as susceptible as sheep then it is likely subacute toxicity exists. The interrelationship between $\mathrm{Cu}$ and other materials such as molybdenum (Mo), cadmium (Cd), $\mathrm{Zn}$, and sulfur (S) is well documented (1) and must also be considered in relation to $\mathrm{Cu}$ toxicity. Zinc antagonizes $\mathrm{Cu}$ accumulation therefore reducing possibility of toxicity and vice versa. Molybdenum is also antagonistic to $\mathrm{Cu}$ but unfortunately it was not analyzed in this study but a previous report has indicated high levels of the element together with $\mathrm{Cd}, \mathrm{Co}, \mathrm{Fe}$ and $\mathrm{Mn}$ in the Kafue water [10]. It should also be noted that the hemolytic crisis can be precipitated by many other stress factors such as a fall in plane of nutrition, fasting and physical effort and as such it is important to consider all these options when analysing toxicity.

In cattle $\mathrm{Zn}$ toxicity was observed after the metal concentration in the liver exceeded $34.2 \mathrm{mg} / \mathrm{kg}$ dry weight [1]. In this experiment concentrations in lechwe were much higher than this figure ranging from $52.0-138.0 \mathrm{mg} / \mathrm{kg}$. Whether these levels can cause toxicity as observed in cattle is not clear as no literature with such information was found. The authors however believe some adverse effects may exist that are either subclinical and difficult to characterise or have been misdiagnosed. A controlled experiment would be required to directly characterise the relationship.

Iron is essential for normal hemoglobin formation by acting as a component of the heme molecule, as a component of myoglobin, in iron containing enzymes and some is bound to iron storage proteins ferritin and hemosiderin [1]. Toxicological considerations are important in terms of accidental acute exposures and chronic iron overload mainly as a consequence of excess dietary iron or frequent blood transfusions. Iron overload results in disturbances in liver function, diabetes mellitus and even endocrinal disturbances and cardiovascular effects particularly in humans. In this study Fe levels in plants and lechwe livers were remarkable suggesting that elevated levels in animals may mainly be as a result of feeding on these plants than from water. Iron toxicity requires chronic ingestion of very high amounts and is antagonized by $\mathrm{Mn}$. It is therefore more likely that toxicity is subclinical in these animals.

The population of wildlife in the Kafue flats has greatly decreased over the years with some species becoming extinct $[9,13]$. Poaching has been cited as the major cause of these reductions but the contribution of other factors, particularly pollution, can not continue to be ignored. Although a lot of legislation is being set up to arrest pollution in the country in general and parks in particular, more needs to be done and identification of markers of pollution or exposure and risks at different levels of the food chain can greatly supplement policy formulation. It difficult to single out any adverse effects that can exclusively point to heavy metals as the sole etiology. However, the high levels of some of these metals suggest the possibility of subclinical conditions existing in these animals that may be masked by interactions between these metals. It is therefore impotant to assess these findings in detail.

The study further raises the possibilities of similar health risks on other dependents of the Kafue Flats including livestock and humans that are exposed. A study already exists which associated cattle deaths upstream the Kafue river to mining waste contamination [15]. Therefore, further studies to evaluate subclinical toxicity in livestock and the public health situation are encouraged.

ACKNOWLEDGMENT. This work was supported in part by Research Project, Grant-in-Aids for Scientific Research (No. 11691165) from the Japan Society for the Promotion of Science.

\section{REFERENCES}

1. Humphreys, D.J. 1988. pp. 15-19. In: Veterinary Toxicology, 3rd ed., Bailliere Tindall, London.

2. Hunter, B.A., Johnson, M.S. and Thompson, D.J. 1987. J. Appl. Ecol. 24: 573-614.

3. Kimball, B.A., Callender, E. and Axtmann, E.V. 1995. Appl. Geochem. 10: 285-306.

4. Ma, W., Denenman, W. and Farber, J. 1991. Arch. Environ. Contam. Toxicol. 20: 266-270.

5. Maclntosh, D.L., Suter, G.W. and Hoffman, F.O. 1994. Risk Anal. 14: 405-419.

6. Martin, J.M. and Whitefield, M. 1983. pp. 265-296. In: Trace Metals in Sea Water (Wong, C.C., Boyle, E., Bruland, K.W., Burton, J.D. and Goldberg, E.D. eds.), Plenum Press, New York and London.

7. Meybeck, M., Friedrich, G., Thomas, R. and Chapman, D. 1992. pp. 239-316. In: Water Quality Assessments. A guide to the Use of Biota, Sediments and Water in Environmental Monitoring (Chapman, D. ed.). UNESCO/WHO/UNEP, Chapman and Hall, Cambridge.

8. Mwase, M., Vicktor, T. and Norrgren, L. 1998. Bull. Environ. Contam. Toxicol. 61: 96-101.

9. Mwima, H.K. 1995. pp. 41-64. Proceeding of the Symposium "The Effects of Enlargement of Domestic Animal Pasture on the Wildlife in Zambia”. Lusaka, Zambia.

10. Norrgren, L., Pettersson, U.T., Orn, S. and Bergqvist, P.A. 2000. Arch. Environ. Contam. Toxicol. 38: 334-341.

11. Pascoe, G.A., Blanchet, R.J. and Linder, G. 1994. Arch. Environ. Contam. Toxicol. 27: 44-50.

12. Suzuki, A.K., Pandey, G.S. and Takahashi, S. 1995. pp. 35-40. Proceeding of the Symposium "The Effects of Enlargement of Domestic Animal Pasture on the Wildlife in Zambia". Lusaka, Zambia.

13. Tembo, A. 1995. pp. 65-75. Proceeding of the Symposium "The Effects of Enlargement of Domestic Animal Pasture on the Wildlife in Zambia”. Lusaka, Zambia.

14. USEPA. 1992. EPA/630/R-92/001. US Environment Protection Agency, Risk Assessment Forum, Washington, D.C.

15. USEPA. 1993. vol I and II. EPA/600/R-93/187. US Environment Protection Agency, Office of Research and Development, Washington, D.C.

16. ZCCM (Zambia Consolidated Copper Mines) 1983. Mining Industry Technical Services. Pollution control department. MITS/PA/30/82. 